Article

\title{
A Portfolio of Effective Water and Soil Conservation Practices for Arable Production Systems in Europe and North Africa
}

\author{
Tshering Choden ${ }^{1, *}$ and Bhim Bahadur Ghaley ${ }^{2}$ \\ 1 Dutch International Business Development Cooperative, Bornsesteeg 28B, \\ 6708 PE Wageningen, The Netherlands \\ 2 Department of Plant and Environmental Sciences, University of Copenhagen, \\ Højbakkegård Alle 30, 2630 Taastrup, Denmark; bbg@plen.ku.dk \\ * Correspondence: tshering.choden@dibcoop.nl
}

Citation: Choden, T.; Ghaley, B.B. A Portfolio of Effective Water and Soil Conservation Practices for Arable Production Systems in Europe and North Africa. Sustainability 2021, 13, 2726. https://doi.org/10.3390/ su13052726

Academic Editor: Bharat Sharma Acharya

Received: 7 February 2021

Accepted: 27 February 2021

Published: 3 March 2021

Publisher's Note: MDPI stays neutral with regard to jurisdictional claims in published maps and institutional affiliations.

Copyright: (c) 2021 by the authors. Licensee MDPI, Basel, Switzerland. This article is an open access article distributed under the terms and conditions of the Creative Commons Attribution (CC BY) license (https:// creativecommons.org/licenses/by/ $4.0 /)$.

\begin{abstract}
To secure sustainable food production for meeting the growing global demand for food, it is imperative, while at the same time challenging, to make efficient use of natural resources with minimal impact on the environment. The study objective is to provide insights into the multiple benefits and trade-offs of different sustainable agricultural practices that are relevant across pedoclimatic zones in Europe and North Africa, including conservation agriculture, crop diversification, organic agriculture, and agroforestry. Widespread adoption of these practices in specific regions depends on the effectiveness with which their applications and attributes are communicated to farmers, and their suitability to local conditions and opportunities. Scale impacts of the practices range from field to catchment levels, but the best empirical evidence has been generated at field level in on-farm and experimental trials. The outcomes from the application of each of these practices depend on variables specific to each site, including pedo-climatic zone, geography, weather, ecology, culture, and traditions. Each practice has trade-offs and the same practice can have different effects when compared to conventional agriculture. To make site-specific recommendations, a careful assessment of overall benefits must be made. Adoption can be stimulated when farmers have the opportunity to experiment on their own land and discover the advantages and disadvantages of different practices.
\end{abstract}

Keywords: agroforestry; conservation agriculture; Europe; North Africa; nutrient retention; organic agriculture; soil conservation; water conservation

\section{Introduction}

One of the major challenges of our time is to secure a steady supply of healthy and nutritious food for a growing world population, while also protecting the environment and mitigating climate change. Agriculture is the main consumer of the world's water and land resources and at the same time an important emitter of greenhouse gases (GHG). Globally, cropland expansion and agricultural intensification continue to be the most widespread form of land use change [1]. The costs of increasing agricultural production has led, in many parts of Europe and elsewhere, to a significant decline in biodiversity across farmlands. Attempts to improve production through large-scale homogenization, including the resulting genetic uniformity, make this type of arable agriculture more vulnerable to pests, diseases, and abiotic stresses [2]. The overuse and misuse of synthetic fertilizers and pesticides has led to very high nutrient emissions to air and water, that damage ecosystems and contribute to GHG emissions. For instance, the discharge of large quantities of nitrates, phosphorus $(\mathrm{P})$, pesticides, soil sediments, and saline drainage from farmlands in water bodies, has caused the eutrophication of habitats, which poses a threat to inland aquatic ecosystems and coastal waters [3]. According to the United Nations World Water Assessment Program report (2015) [4], in the European Union, 38\% of water bodies are affected by agriculture pollution and overuse, which is further aggravated by 
increased sediment runoff and groundwater salinization and the depletion of groundwater supplies. In addition, agricultural intensification is often accompanied by highly intensive tillage practices which has led to reductions in organic soil matter and soil biodiversity, causing very serious soil degradation [5].

At the core of the efforts to address the aforementioned social and environmental shortcomings of conventional agriculture is the promotion of a transition from conventional agriculture-with high levels of use of agro-chemicals, simplification of the agro-ecosystem, and dangerous levels of environmental pollution-to more diversified and sustainable forms of agriculture [6,7]. Such a transition will require more widespread adoption of sound agricultural practices that make more efficient use of water and soil than is currently the case. This shift in practices should minimize water and nutrient inputs (e.g., irrigation and excessive $\mathrm{P}$ application), reduce greenhouse gas emissions through more efficient fertilizer and fuel use for operational activities, and prevent environmental pollution while providing stable, and, where feasible, increased crop yields [8].

The major problems resulting from homogenized and intensified agricultural systems are aggravated by increasingly widespread and intense climate change impacts on production systems. The degree of these impacts varies regionally. There is already a perceptible northward shift in European agro-ecological zones, which is predicted to accelerate in the next decades [9]. Crop productivity is projected to increase in northern Europe under multiple climate change scenarios, due to increasing precipitation and warmer temperatures, while it could decrease in southern Europe due to increasing aridity [10,11]. At the same time, climate variability is also increasing in Europe, and extreme weather events are predicted to be more frequent [10]. Productivity gains in the north, therefore, are predicted to be countered by the increasing frequency and duration of extreme weather events that cause lodging and flooding from higher rainfall, adversely affecting field accessibility and diminishing the reliability of achieving target yields [12]. These natural hazards leave farming systems vulnerable to economic stress and threaten food security goals [13,14].

There is consistent agreement among global climate change model projections that the Mediterranean Basin region will experience reductions in precipitation in almost all seasons, but particularly in the summer, except in the most northern parts (where lower precipitation in winter is predicted), causing serious problems of low and fluctuating water supply [15-17]. Increasing temperature is also projected during all seasons throughout the Mediterranean Basin as well as higher daily precipitation extremes [16]. Moreover, overexploitation of ground water for irrigation has caused salinization, leading to soil degradation and loss of soil fertility, particularly in North Africa, while extreme rain events have resulted in severe soil erosion, landslides, and flooding. The implication of these projections of a changing climate is that the effects of certain agricultural practices and the suitability of certain crops will also change over time, necessitating the use of more adaptive and effective management approaches. For example, heavier rainfall in hilly regions will necessitate more terracing and/or better soil coverage to prevent soil erosion. Longer dry periods will require better soil coverage with mulch, crop residues, or vegetation to improve soil moisture retention [16].

Both water deficiency and flooding, the likelihood of which is increasing due to climate change, will variably either destroy crops or limit crop growth and production potential. On the other hand, excessive and inappropriate use of water can increase production costs. The excessive and ill-timed application of fertilizers to cropping systems can cause considerable nutrient flows into the ground water and in the surrounding water bodies, thus, affecting surface and groundwater quality and aquatic ecosystems [17]. To address these challenges, agricultural practices that improve the delivery of an array of ecological, agronomic, and social benefits from farming systems are needed. These practices should not only optimize crop yield per unit of water (water use efficiency) and per unit of nutrient (nutrient use efficiency), but also increase ecosystem services, produce healthy food, and support sustainable farming enterprises (increasing eco-effectiveness) while improving social factors through yield stability and lower input costs (economic parity) [6,18,19]. 
In this article, the objective is to provide insights into the multiple benefits and tradeoffs of different sustainable agricultural practices that are relevant across the pedo-climatic zones of Europe and North Africa. We contextualize these trade-offs according to a set of site relevant ecological, agronomic, and economic indicators. Such an analysis remains urgently needed considering that wider uptake of sustainable practices is still not taking place in many parts of the world, including Europe and North Africa [20], despite research that has demonstrated that multiple benefits (including clear 'win-win' outcomes) can be generated [21]. There are many nuanced reasons for this slow uptake of beneficial techniques, such as policy impediments (e.g., lack of incentivization), economic barriers, and knowledge gaps concerning the complexity of spatial, temporal, and crop component interactions of more dynamics agricultural systems [22]. It is important to note that this article does not present and assess examples and experiences from developing countries nor does it aim to compare the European and North African situations with other countries or continents.

The analysis presented in this paper can assist European and North African farmers to make better informed decisions according to their respective local conditions and opportunities. The practices we analyzed, empirically verified in on-farm and experimental trials, resulted in improvements in multiple key performance indicators, such as primary productivity, water conservation, soil conservation, nutrient regulation, biodiversity, and climate regulation. They have been selected for their implementation potential, but with the caveat that local conditions will require agile adaptation at any given site. Our study offers a novel approach by broadening the perspective beyond crop yield only. The analytical results also contribute to policy debate and policy review towards achieving a more sustainable agriculture, which is high on the policy agendas in Europe and North Africa. It has direct policy relevance regarding the implementation of the European Union's revised Common Agriculture Policy (CAP), which now has a very strong environmental and climate focus. At the same time, national and regional governments in Europe and North Africa are working on policy review toward circular economies and a circular agricultural sector, which could benefit from the practical, evidence-based strategies and practices analyzed in this study.

Following this introduction, Section 2 describes the materials and methods; Section 3 presents the results; Section 4 details the discussion; and Section 5 finishes with concluding remarks.

\section{Materials and Methods}

A thematic literature search on sets of sustainable agriculture practices was conducted for six countries of Europe and North Africa representing diverse climatic conditionsDenmark, the Netherlands, Germany, Italy, Egypt, and Tunisia. The goal was to assess the impact of these agricultural management practices based on six components: soil use, nutrient use, water use, biodiversity, agronomic productivity, and profitability. For each of the six components, a number of indicators was identified (Table 1). The literature search was conducted in the Web of Science database and by using the Google Scholar advanced search, focusing on references published between 2000 and 2020. This search was meant to be neither exhaustive nor systematic, but rather to identify research papers, including meta-analyses, that report on the outcomes of either on-farm or experimental research of sustainable agriculture practices that offer information about management impacts on the six components. The practices selected were not decided a priori, but emerged from a preliminary search using the phrase "soil and water conservation" and "agriculture". The refinement of the initial search terms was made after the preliminary search and limited to relevant terms within the subject areas using the key words "conservation agriculture", "crop diversification", "agroforestry", "organic agriculture", and "intercropping" and either "Europe" or "North Africa." 
Table 1. Agriculture system indicators under six components.

\begin{tabular}{cc}
\hline Component & Indicator \\
\hline Soil use & Physical properties \\
& Chemical properties \\
Nutrient use & Amount of total N, P, and potassium (K) \\
& Amount of soil carbon \\
& Nitrogen use efficiency \\
Water use & Nitrogen surplus \\
& Water dynamics and use (quantity and quality) \\
Actual evapotranspiration & Water use efficiency \\
Biodiversity & Crop and varietal diversity \\
Productivity & Crop yield, crop yield stability \\
& Total agricultural inputs \\
& Total agricultural outputs
\end{tabular}

Source: Adapted from a set of SMART agriculture system components and indicators identified by the WaterFARMING project.

\section{Results}

The results of the literature review on the impact of different sustainable agricultural practices on soil, water, and nutrient conservation are summarized in the following subsections and in Table 2. Table 2 presents the assessment of different sustainable agriculture practices that allow the comparison of the effectiveness of each of the practices on nutrient dynamics, water dynamics, productivity, soil use, biodiversity, and profitability (in terms of positive, negative or neutral outcomes). The table also allows the identification of 'win-win' outcomes and trade-offs between options.

One particular category of practices that includes mechanical practices for soil and water conservation (contour farming, terracing, geotextiles, and the use of earth mats) and for vegetative soil and water conservation practices (buffer strips), which can be used from farm to landscape scales, will not be reviewed in detail. Contour farming and terracing are earth engineering strategies that change the direction of water flow from down slope to along an isoline, following the contour of the terrain. Contour farming is useful for soil and water conservation in hilly and sloping landscapes, especially in areas of high precipitation. It reduces water runoff and, therefore, soil erosion, ultimately improving the downstream water quality. The use of geotextiles in fields can decrease water runoff and soil erosion and may help to reduce soil water evaporation. Buffer strips are patches on the farm set aside to maintain semi-natural vegetation that can serve as wind breaks to reduce soil erosion by wind and to create micro-climates conducive for certain crops/trees. They can serve to protect aquatic ecosystems by buffering the movement of soil, water, and nutrients from the field(s) to waterways.

\subsection{Conservation Agriculture}

Conservation agriculture (CA) is a farming system designed to save farming resources, sustain farm production, and achieve acceptable profits while maintaining the functional ecology of the farm system and meeting environmental conservation targets [23]. To achieve these objectives, practices are employed to enhance natural biological processes and ecological interactions above and below ground, through optimizing the management of soil, water, and nutrients $[18,24,25]$. CA is most widely recognized for the positive outcomes of a reduction of both soil erosion and water runoff, and the reduction of pollutants to downstream aquatic systems $[18,26]$. 
Table 2. The summary on effects of agricultural practices on soil and water conservation and on other variables. The effects are compared to conventional tillage and use of agrichemicals. (Effect indicators: $\uparrow$ positive, / neutral, $\downarrow$ negative).

\begin{tabular}{|c|c|c|c|}
\hline Practice & Soil Conservation & Water Conservation & Other \\
\hline Cover/catch crops & $\begin{array}{c}\uparrow \text { soil structure } \\
\uparrow \text { soil erosion } \\
\uparrow \text { soil organic matter (SOM) }\end{array}$ & $\begin{array}{c}\uparrow \text { soil moisture } \\
\uparrow \text { soil water capacity } \\
\uparrow \text { runoff } \\
\uparrow \text { water quality downstream }\end{array}$ & $\begin{array}{c}\uparrow / \downarrow \text { crop yield } \\
\uparrow \text { nutrient regulation } \\
\downarrow \text { weeds } \\
\uparrow \text { biodiversity }\end{array}$ \\
\hline Residue retention/mulch & $\begin{array}{c}\uparrow \text { soil erosion } \\
\uparrow \text { SOM }\end{array}$ & $\begin{array}{c}\uparrow \text { soil moisture } \\
\uparrow \text { evapotranspiration } \\
\uparrow \text { runoff }\end{array}$ & $\begin{array}{l}\uparrow \downarrow \text { crop yield } \\
\uparrow \text { weeds } \\
\uparrow \text { fungus }\end{array}$ \\
\hline No-till/direct seeding & $\begin{array}{l}\uparrow \text { soil erosion } \\
\uparrow \downarrow \text { SOM }\end{array}$ & $\begin{array}{c}\uparrow \text { soil moisture } \\
\uparrow \text { soil water capacity } \\
\uparrow \text { runoff } \\
\uparrow \text { water quality downstream }\end{array}$ & $\begin{array}{c}\downarrow / \uparrow \text { crop yield } \\
\uparrow \text { nutrient regulation } \\
\uparrow \text { weeds } \\
\uparrow / \text { pests }\end{array}$ \\
\hline Minimum tillage & $\uparrow \mathrm{SOM}$ & $\begin{array}{c}\uparrow \text { soil moisture } \\
\uparrow \text { soil water capacity }\end{array}$ & $\begin{array}{l}\downarrow \text { crop yield } \\
\uparrow \text { weeds }\end{array}$ \\
\hline Crop rotation & $\begin{array}{c}\uparrow \text { soil structure } \\
\uparrow / \text { SOM }\end{array}$ & $\uparrow$ soil water capacity & $\begin{array}{c}\downarrow \uparrow \text { crop yield } \\
\uparrow \text { nutrient regulation } \\
\uparrow \text { weeds } \\
\uparrow \text { crop diversity }\end{array}$ \\
\hline Intercropping & $\begin{array}{c}\uparrow \text { soil structure } \\
\uparrow / \text { SOM }\end{array}$ & $\uparrow$ soil water capacity & $\begin{array}{c}\downarrow \uparrow \text { crop yield } \\
\uparrow \text { nutrient regulation } \\
\downarrow \text { weeds } \\
\uparrow \text { crop diversity }\end{array}$ \\
\hline Organic agriculture & $\begin{array}{c}\uparrow \text { soil structure } \\
\uparrow / \text { SOM }\end{array}$ & $\uparrow$ soil water capacity & $\begin{array}{c}\downarrow / \text { crop yield } \\
\uparrow \text { nutrient regulation } \\
\downarrow \uparrow \text { weeds } \\
\uparrow \text { crop diversity }\end{array}$ \\
\hline Agroforestry & $\begin{array}{l}\uparrow \text { soil structure } \\
\downarrow \text { soil erosion } \\
\uparrow \text { SOM }\end{array}$ & $\begin{array}{l}\uparrow \text { soil water capacity } \\
\uparrow \text { evapotranspiration }\end{array}$ & $\begin{array}{c}\uparrow \text { crop yield } \\
\uparrow \text { nutrient regulation } \\
\uparrow \text { weeds } \\
\uparrow \text { crop diversity } \\
\uparrow \text { micro-climate } \\
\uparrow \text { carbon sequestration }\end{array}$ \\
\hline
\end{tabular}

At the same time, in some studies, $\mathrm{CA}$ is associated with negative outcomes in the form of reduced crop yield and increased weed population and weed diversity [27]. Pittelkow et al. (2015) [28] found in a global meta-analysis that yields are on average $5 \%$ lower than in conventional agriculture and found an overall yield decrease $(-8.5 \%)$ in a metaanalysis of CA in European countries [24]. CA in dry climates appears to result in the least reduction in crop yields [29]. The lower yield can be caused by a number of factors, such as slower rate of soil fertility buildup, waterlogging during the periods of prolonged rainfall on poorly aerated soils, delayed crop establishment due to occasional wet and cold soils, fertilizer placement, residue management problems, increased weed competition, residue-borne diseases, and soil compaction. In the following sections, outcomes attributed to CA practices are described in more detail under the three principles of CA: permanent soil cover, minimal soil disturbance, and diversification of crop species.

\subsubsection{Maintaining Vegetation Cover/Permanent Soil Cover}

Maintaining vegetation cover on fields helps to retain nutrients in the root zone, protect the soil surface against erosion and nutrient losses, and minimize the risk of surface runoff by improving infiltration. It also enhances soil water holding capacity, reduces evaporation, and assists in soil structure formation through the maintenance of root systems. Practices that enhance these services include cover cropping or catch cropping, mulching of crop 
residues, intercropping, and using perennial crops. The use of cover crops is a form of usually asynchronous intercropping, as the cover crop is planted in the field between two crop cycles. The cover crop is not grown for harvest or a commercial yield, but rather as a companion plant that provides a set of ecosystem services [30]. Cover crops, such as alfalfa, clover, lucerne, and vetch, which are grown in Europe and North Africa, can also be produced as a secondary understory crop under an existing crop, where they germinate, establish, and then continue to grow after the main crop is harvested. Among the reasons to use a cover crop are the reduction of nitrogen leaching to groundwater [31] and weed pressure reduction, ultimately diminishing the use of herbicides and/or labor inputs [30,32]. Weed control will also contribute to positive environmental and economic impacts.

Important benefits of cover cropping include reduced soil erosion and soil nutrient loss, improved resilience of the crop system against weather variability and climate hazards, and improved soil chemical and physical properties. Incorporating cover crop biomass in the soil can enhance soil structure and, thus, water infiltration. Legume cover crops (e.g., subterranean clover and common vetch) increase soil organic matter, which can reduce the amount of nitrogen fertilizers used [33]. Increases in yield of the subsequent or companion cash crop are found especially with the use of legume species as a cover crop, and the subsequent incorporation of the cover crop residue in the soil $[18,30]$. Cover cropping in Mediterranean systems appears to be very effective, notably for sediment retention and runoff reduction, thereby contributing to soil erosion control [18]. However, yields do not always increase [30]. Cover cropping can sometimes result in reduced yield of subsequent cash crops as cover crops compete for soil nutrients and water [16,30]. One study showed that the effects of lacy phacelia, white mustard, and hairy vetch mulching on soil quality, microbial functions, and crop yield, were negatively influenced by variable summer precipitation and temperature [34].

Crop residue retention and mulching help to conserve soil moisture, reduce soil erosion and water runoff and retain nutrients in the field. Based on field research results from Tunisia, mulching (residue retention) is more effective than conventional tillage (under both semi-arid and sub-humid conditions) in enhancing yield of wheat (15\% higher), water use efficiency (18\% versus $13 \%)$, and soil organic carbon accumulation $\left(0.18 \mathrm{t} \mathrm{ha}^{-1} \mathrm{y}^{-1}\right.$ versus $\left.0.13 \mathrm{tha}^{-1} \mathrm{y}^{-1}\right)$. This practice is effective in preventing erosion $\left(1.7 \mathrm{t} \mathrm{ha}^{-1} \mathrm{y}^{-1}\right.$ versus $4.6 \mathrm{t} \mathrm{ha}^{-1} \mathrm{y}^{-1}$ of soil loss) [15,18], and it limits evapotranspiration from the soil [35]. The effect of cover crops and residue mulching on weed suppression depends on cover crop species used and the target weed species [36]. Residue mulching is most beneficial in arid and semi-arid environments, where soil moisture is a limiting factor. Its use in cooler and wetter regions can cause too much soil moisture and the growth of fungus and outbreak of diseases [18].

It is important to note that in many farming systems crop residues are taken off the field for use as feed for livestock or fuel for energy [37]. Thus, retention of crop residues on the field carries an opportunity cost that some farmers may not be willing to bear. Operational costs may be another factor that influences adoption, as crop residue incorporation can be more expensive compared to burning and removal of crop residue.

\subsubsection{Minimizing Soil Disturbance}

CA aims to minimize soil disturbances with the goal of reducing soil erosion and nutrient loss. Practices include no-tillage and minimum tillage. No-tillage or direct seeding is when the soil surface is not broken at any point other than for the drilling of small holes for planting. Sowing occurs directly in the stubble by cutting or "drilling" narrow slots for seed. Whereas minimum tillage in experimental trials often refers to a practice whereby only the near-surface soil $(5-10 \mathrm{~cm})$ is physically disturbed with discs, chisels, or a field cultivator, but generally without inverting the soil, resulting in loose topsoil. One objective of no-tillage and minimum tillage is to reduce the disturbance of the microbiological community, such as fungal networks whose exudates help ensure soil aggregate formation and stability [38], while also reducing the exposure of soil and, therefore, lowering erosion 
potential, moisture loss, and water runoff. The environmental benefits of no and minimum tillage at the farm level include the conservation of soil in the fields, and at the catchment scale, reduced sedimentation and run-off losses to downstream water bodies. The practice reduces labor inputs and the use of heavy machinery (and fuel) and, thus, can lower production costs as well [28].

CA is not only a theoretical concept, but has demonstrated economic and practical benefits in Europe and North Africa. For instance, no-tillage is being adopted at an increasing rate in southwestern Europe and North Africa, as it has produced winter crop yields that are higher or equal to systems using the conventional tillage [27]. Furthermore, no-tillage or minimum tillage, coupled with either $50 \%$ or $100 \%$ fertilizer application rate and weed control, gave better crop yields than conventional tillage in an experiment on exhausted clay soils in Egypt [39]. However, in Tunisia, different tillage practices (no-tillage combined with rotation and conventional tillage) coupled with different rates of fertilizer did not alter the grain yield, nitrogen content in grain, or nitrogen use efficiency. No-tillage combined with crop rotation enhanced the grain yield, nitrogen content in grain and nitrogen use efficiency [40]. Despite these benefits, other studies have shown that direct drilling with no-tillage resulted in significantly lower crop yields compared to ploughing. The tillage effect on crop yields was consistent across the crop species, though differences exist between crop species [41-43]. In one study of no-tillage use, weed infestation was found to be about 2-20 times higher compared to conventional tillage [41]. In another study it was shown that, with differing degrees of tillage, the effect on weed density varied. Under conventional tillage, the weed density decreased up to $71 \%$ while in minimum tillage and no-tillage the weed density reduction was up to $85 \%$ and $61 \%$, respectively [44].

Other studies comparing no-tillage to conventional tillage have reported significantly higher levels of soil organic matter and total nitrogen in the top $30 \mathrm{~cm}$ soil layer, but the bulk density and total soil porosity of soil was enhanced only in the top $10 \mathrm{~cm}[45,46]$. In contrast, studies carried out in northern Tunisia showed no increase in soil organic matter or soil organic carbon, even after 15 years under both no-tillage and CA [47]. A similar result was obtained after four years of experimental trials [48] under both no-tillage and CA. A study carried out in Egypt showed significant differences in soil physical properties with increased soil infiltration in minimum tillage (with a depth of $15 \mathrm{~cm}$ ) that was $48 \%$ and $65 \%$ higher than that obtained when tillage depth increased to $20 \mathrm{~cm}$ and when compared with conventional tillage (with a depth of $25 \mathrm{~cm}$ ), respectively; furthermore, the runoff and soil loss were lower ( $4.91 \mathrm{~mm}$ and $0.65 \mathrm{tha}^{-1}$ ) under minimum tillage compared to conventional tillage (11.36 $\mathrm{mm}$ and $\left.1.66 \mathrm{t} \mathrm{ha}^{-1}\right)$ [49].

In another study under semi-arid conditions in North Africa, after four years, no-tillage significantly improved soil nutrient content, especially $\mathrm{K}$, potassium oxide, phosphorus pentoxide, and N [48]. In that study, the improvement of soil properties gained via notillage depended on factors, such as tillage management, sites (climate and soil type), and crop succession (crop species and cover crop residue). Conservation tillage, especially coupled with residue retention and cover cropping, has positive effects on soil water storage in semi-arid, rainfed conditions. The soil water storage capacity increases with application of conservation tillage systems and with increasing aridity. For instance, one study showed that grain yield and stability were positively correlated with soil water storage, especially in years with lower mean yield production [50]. Wheat water use efficiency was highest under no-tillage with residue retention, according to a study done in Tunisia [15]. In a study carried out in Denmark, the combination of no-tillage with cover crops demonstrated a better soil friability [51]. The reviewed studies demonstrated the capacity of no-tillage CA to improve soil properties that in turn have positive downstream consequences on water flow, water storage, and resulting plant productivity.

Although there are clearly demonstrated benefits of no-tillage practices, it remains important to analyze if there are tradeoffs when deciding management actions. There are a variety of contextual factors, such as degree of tillage and residue retention, that determine the likely outcomes of management actions. The desired outcomes, from biodiversity to 
productivity, must, therefore, be considered when deciding on any suite of management actions as summarized here. For instance, the use of occasional shallow inversion tillage in an otherwise no-tillage system can help incorporate organic matter into the soil, improve the topsoil structure for increasing water infiltration and water holding capacity, control weeds, and increase soil carbon stocks [29]. The retention of crop residues on the soil surface with no-tillage has also led to more active soil organic carbon dynamics in the top layer $(0-5 \mathrm{~cm})$ under the conservation system, while in conventional farming, ploughing helped to incorporate the residues and soil organic carbon accumulation at the $30-50 \mathrm{~cm}$ depth [52]. Minimum tillage in combination with organic farming was found to be an effective agricultural strategy to enhance soil microbial biomass, microbial residues, and bacterial and fungal abundances [53]. In a study conducted using conventional tillage (25 cm depth), reduced tillage $(7.5 \mathrm{~cm}$ depth), and no-tillage, the highest crop yield observed was up to $2.4 \mathrm{t} \mathrm{ha}^{-1}$ under reduced tillage and the lowest yield of $1.1 \mathrm{t} \mathrm{ha}^{-1}$ under notillage [44]. These experimental findings confirm the need to carefully assess the relative benefits and costs of each tillage option.

\subsubsection{Crop Rotation}

The third principle of CA involves crop rotation, which is the sequential cultivation of crops in the same field instead of planting the same crop species, either from one year to the next, or within a year. Crop rotation increases field level diversity and enables the genetic, temporal and spatial benefits of crop diversification [54]. As different crops have different nutrient requirements, interactions with soil micro-organisms, rooting strategies, and physiology, crop rotation can help balance site dynamics by regulating soil nutrients, building soil structure, suppressing weeds, and decreasing pests and diseases. By choosing a suitable crop sequence, the pre-crop can help to meet the nutritional requirements for the growth of following crop(s) [54]. Moreover, the success of crop rotation systems to suppress weeds is based on the use of crop sequences that create different patterns of resource competition, allelopathic interference, soil disturbance, and temporal field coverage, all of which can prevent the proliferation of a particular weed species [55]. For instance, planting deep-rooted cover crops in rotations helps to distribute $\mathrm{P}$ and $\mathrm{K}$ and capture the unused nutrients. Planting a shallow-rooted crop, followed by a deeper-rooted crop can help to recover nutrients that were not used by the shallow feeder and which might have leached by irrigation or rainfall to lower layers of the soil profile [56].

Crop rotation is also beneficial for the control of pests and diseases. In Tunisia and the Mediterranean region at large, the use of break crops, such as faba bean and vetch as pre-crops, was demonstrated to be effective for reducing Fusarium culmorum inoculum in the soil and the pathogen in wheat roots and stem bases [57]. When durum wheat was cultivated following legumes or vegetables, it showed greater $\mathrm{N}$ uptake, but with only a minor effect on its conversion to grains [58]. Cowpea and gaur pre-crops cultivated before lentil gave the greatest reduction in disease severity. Lentils cultivated after cowpeas produced the highest seed yield followed by gaur and millet. Lowest lentil seed yield production was recorded when plants were cultivated after soybean, followed by sesame and groundnut [59]. Findings from Denmark showed that when a continuous winter wheat cropping was compared with a winter oilseed rape-winter wheat-winter wheat-winter barley crop rotation system, the former had higher grain yield ( 83.5 grain yield ha ${ }^{-1}$ ) than the latter (72.9 grain yield ha ${ }^{-1}$ ) [60]. In contrast, when a winter oilseed rape-winter wheat-winter rye-peas-winter wheat-winter barley crop rotation system was compared with a winter oilseed rape-winter barley-alfalfa/clover/grass-mixture-winterrye-silage maize-winter wheat crop rotation system in Germany, the grain yield for the latter crop rotation system was higher yielding (72.9 grain yield ha $\left.{ }^{-1}\right)$ than the former (70.0 grain yield ha ${ }^{-1}$ ) [60].

These findings suggest that the proper sequencing of crops in time and space and the informed use of nitrogen fixing crops and cover crops are important to obtain optimum results. The inclusion of legumes in crop rotations can supply biologically fixed atmospheric 
nitrogen due to the capability of legumes, making it available to the succeeding crops in rotation, thus, reducing the necessity for external inputs [61,62]. However, the long-term effects of these practices on various indicators are relatively unknown. A rare exception is the work by Götze et al. (2016) [63] that concluded that after 41 years, there were no significant differences in total carbon and microbial biomass carbon content among different crop rotations. More of such longer-term studies could be of great help to improve the design of effective crop rotations.

\subsubsection{Intercropping}

Arable production systems characterized by fields of annual crops are dominated by the use of monocultures, where a single crop species is produced at any given time (i.e., "sole crop"). A variation on sole cropping is intercropping, where two or more crop species are grown simultaneously in the same field for some duration [64]. Intercropping designs vary by crop species and varieties, combination proportions, spatial layout and densities, fertilizer inputs, and timing of sowing and harvesting. All these variables affect the impact on the key indicators of sustainable agriculture, further depending on climate, soil type, surrounding vegetation, and land use history. In general, intercropping has been found to increase crop productivity and crop yield stability [65], though not always significantly [66], while also reducing fertilizer inputs $[67,68]$ and the use of herbicides $[31,66]$. One critical measure of the advantages of intercropping is the land equivalent ratio (LER) [69], which is a ratio of the summed productivity of the intercropped components compared to the component sole crops. An LER >1.0 indicates higher overall yield of the intercropped crops per unit of land compared to sole cropping. Intercropping is used most notably in organic farming systems, as it reduces fertilizer needs through exploitation of interspecific complementarity, conserves soil moisture, and provides strong competition with weeds [64]. It is, therefore, suggested that cereal-grain legume intercropping is most advantageous in systems with low nitrogen availability [64].

In intercropping, the yield improvements are mainly due to facilitation (positive interspecific interactions) in resource use, resource sharing, and niche complementarity between different crops, thus, enabling the achievement of higher yields than in monoculture. Another advantage of intercropping is the reduced downstream consequences of the biodynamic system on plant health. Work by Hauggaard-Nielsen et al. 2008 [66], has demonstrated the decrease of disease in intercrops in the range of $20-40 \%$ when compared to sole crops. Research findings from Italy have demonstrated that the soil carbon retention was promoted by preceding intercropped legumes making mineral nitrogen available and enabling the succeeding crop to achieve adequate yield [70]. In some cases, intercropping has shown an increase of carbon sequestration in above ground biomass and soil carbon under a 2:1 barley and pea organic system in Europe [71]. Intercropping can also increase water use efficiency in arid and semi-arid regions [72], but results vary. In experimental trials in Egypt, intercropping was found to result in an LER slightly above 1.0, but it did not increase the water use efficiency (WUE) when compared to conventional cropping [73]. In contrast, one study has shown that intercropping winter wheat with clover led to a decrease of wheat grain yield by 10-25\% compared to the wheat sole crop [74]. The different advantages and tradeoffs of intercropping, therefore, merit further consideration, which can be assessed with the use of crop-system modelling that can appropriately simulate crop combinations and outputs under given environmental and management contexts.

\subsection{Organic Farming}

Organic farming is characterized by the prohibition of the use of synthetic pesticides and fertilizers, with the objective of balancing productivity with environmental sustainability [75]. Unlike conventional farming, organic farming practices depend on a long-term, integrated, and cyclical approach of nutrient management. Organic agriculture in its purest form is a closed system based on the circular dependence of livestock and plant crops [76]. The green manure grown on the farm and the crop residues produced are returned to 
the soil. Upon decay, they enrich the soil with organic matter and to a lesser extent with nutrients, such as $\mathrm{N}$ and P. Most commonly, organic farmers practice a six-year crop rotation, which meets the requirement for soil health, weed suppression, and protection against pests and diseases. Organic farming can be combined with CA, but the generally poor performance of $\mathrm{CA}$ on weed and pest control necessitates the use of labor-intensive biological and mechanical control measures for weeds and pests [75].

Integrated organic farming systems strive to reduce the need for off-farm inputs, which consequently lowers greenhouse gas emissions [77]. In organic agriculture, the introduction of a legume in the crop rotation as well as in an intercropping system improves soil fertility (soil organic carbon, humus content, and making $\mathrm{N}$ and $\mathrm{P}$ available). However, the $\mathrm{N}$ contribution by legumes varies considerably depending on legumes species and the local soil and climatic conditions [77]. For example, in a conventionally managed system, both $\mathrm{N}$ input and output were observed to be higher when compared to the organic farming system, in which grass-clover was rotated with the main crop, and when compared to a grain-legume organic cropping system [78]. However, it has also been shown that total soil organic matter content between the soil depth of 0 and $20 \mathrm{~cm}$ was higher for organic farming system $\left(24 \mathrm{~g} \mathrm{~kg}^{-1}\right)$ compared to conventional farming system $\left(15 \mathrm{~g} \mathrm{~kg}^{-1}\right)$ [79]. The total organic carbon and soil $\mathrm{N}$ pool increased over a longer period of organic farming practices as well $[80,81]$. The $\mathrm{N}$ loss from the organic farming was comparable to conventional farming, and the amount of $\mathrm{N}$ loss through leaching was dependent on soil type, climate, the use of catch crops, and the amount of soil organic matter [81]. However, various studies have demonstrated that the crop yields under organic systems are generally $20-50 \%$ lower when compared to conventional cropping systems, but results are highly dependent on the particularity of the systems and site characteristics, such as available nutrients, soil management history, climatic conditions, and technology [7,82-84]. Yield quality, however, is usually higher than under conventional cropping systems.

\subsection{Agroforestry}

Agroforestry includes practices that integrate, preserve, and manage perennial woody species in productive systems of annual or perennial agricultural crops, either in orderly plantations or where a diversity of crop types and species are combined in highly integrated, multistrata systems. Agroforestry in arable farming systems, or silvo-arable systems, involves the establishment of alleys of trees, usually fruit, timber, or bioenergy, with annual crop intercropping that usually uses cereals [85]. Agroforestry systems deal with yield diversification and the production of a short-term return on land while the planted trees are still small. Integrating trees in arable farming systems in Europe has multiple advantages, which have been assessed by the Agforward project, among others [86-89]. These include increasing diversification of crops, which can reduce risks in the event of a single crop failure; obtaining revenue from annual crops that can subsidize the investment in the future tree crops; and a host of ecosystem services, including modified microclimates, reduced soil erosion, improved soil structure, reduced $\mathrm{N}$ leaching, improved nutrient cycling, and above ground and below ground carbon sequestration. Additional benefits include improving the landscape aesthetic, increasing biodiversity, and providing bio-mulch to suppress weeds.

Agroforestry in arable systems can also increase or maintain grain crop yields when compared to cereal monocultures per unit area of land. For example, the grain yield of some barley varieties was higher in an agroforestry system of walnut trees and cereal than as a monocrop [88]. Agroforestry systems are particularly beneficial in arable and semi-arable climates. Although trees compete with adjacent crops for water and nutrients, the deeper rooting systems of trees can capture drainage water, including during the fallow time [90]. Furthermore, through the process of hydraulic lift, water and nutrients from deeper soil horizons can be drawn up and released in the upper horizons, benefiting shallower rooted plants. Another advantage of agroforestry is the capacity to modify the microclimate through temperature regulation from tree shading [91]. For instance, a study conducted in Germany [91] found increasing soil temperature in a soil depth of $50 \mathrm{~cm}$ as 
the distance from the trees increased, with the lowest value within the trees and the highest at $7 \mathrm{~m}$ distance. The effect of trees was strongest during summer months, with diminishing effect during the winter months.

When a high input conventional farming system was converted to an agroforestry system, dry matter yield and land-use efficiency were negatively affected. However, when a low-input organic farming system was converted to agroforestry, dry matter yield and land-use were higher [92]. However, despite having many potential benefits, due to higher overall management costs and mechanization problems compared to conventional agriculture systems, farmers are reluctant to adopt agroforestry systems [8]. As a result, across Europe and the Mediterranean region, agroforestry systems remain a niche practice.

\section{Discussion}

\subsection{Multiple Benefits and Trade-Off Analysis}

Based on the literature review and building upon the study carried out by Wezel et al. (2014) [20], it is evident that all the sustainable agricultural practices analyzed provide multiple benefits, such as water conservation, soil conservation, nutrient regulation, biodiversity, crop yield, pest, disease and weed control, and climate regulation. However, when comparing practices, there are trade-offs to be considered, in terms of benefit type, level, visibility, and time and duration of occurrence, as well as inputs required. Some of the practices described here may be directly economically advantageous to the farm, for instance, by increasing crop yield and/or by reducing labor requirements or chemical inputs. Others are beneficial in ways that are more nuanced and/or have long-term or larger-scale benefits. Most sustainable agricultural practices also have non-monetary advantages, such as reducing greenhouse gas emissions, reducing soil erosion, and the consequent sedimentation of downstream aquatic ecosystems. The reduction in greenhouse gas emissions through no-till farming, for example, has far-reaching global and long-term benefits, but it may not directly benefit the farm itself in the short term. Considering the variation in pedo-climate, geography, weather, ecology, cultures, traditions, seed quality, and subtle differences in implementation of the practices at experimental and field-trial locations, generalizing about the effectiveness of these practices for any given region is difficult. This is an important point for further study and analysis, for example, by means of improvement of crop system models that can allow decision-making to be critically evaluated given desired outcomes and pedo-climatic contexts. The incorporation of more data in crop system models, especially considering the importance of developing accurate tools for simulating intercrop dynamics, is an important avenue for the increased uptake and adoption of sustainable agricultural practices.

\subsection{Constraints of Implementation of Sustainable Agricultural Practices}

Implementing the sustainable agriculture practices analyzed here is not limited by one explicit obstacle or a particular constraint. The constraints are more a consequence of several issues that interact and are case-specific. In the following section, an overview of constraints is given. The constraints are (i) high costs of implementation, (ii) ineffective incentives and lack of transition schemes, (iii) low levels of education and awareness; and (iv) lack of and limited field demonstrations.

\subsubsection{High Costs of Implementation}

Transiting toward sustainable farming practices requires fundamental changes in soil-crop-landscape system management, including design, implementation, and monitoring. Farmers must adjust the nature and scale of farm operations and the degree of mechanization. The scale and degree of mechanization required for profitable farms usually leads to large up-front adoption costs of these practices, which locks farmers into a status quo preference, as they cannot afford any risk given their input and potential debt. Being (un)able to afford the expense of transitioning management practices to novel methods is one of the common barriers to the adoption of sustainable farming practices $[93,94]$. Other 
barriers toward the transition to more sustainable practices are the high labor intensity and high labor costs, particularly in Europe [91]. Additionally, low profitability is still a major concern of farmers and landowners considering adoption of these practices [95]. There is, therefore, a need to convince farmers of the risks involved and provide them tools that help depict the consequence of their actions.

\subsubsection{Ineffective Incentives and Lack of Transition Schemes}

Although in Europe several incentives (schemes) have been designed, such as incentives to promote agroforestry through Pillars I and II of the CAP, they are often limited in practice. The Pillars I and II incentives are only for establishing new agroforestry systems and not for adjusting/improving those already in existence [95]. Likewise, there are marketbased incentives that promote the adoption of intercropping and residue mulching, but not for adoption of no-tillage [96]. The externalities generated by conventional practices, and the difficulty of quantifying them and the context of ecosystem services, have contributed to this lack of emphasis on more nuanced and larger-scale benefits, such as those achieved by no-tillage. Under the current CAP provision, the payment for a single farm is not linked to any cropping system or soil management protocol or to any scheme that offers payment for environmental services [96]. Overall, there is an absence of adequate policy and institutional support for the farmers to transit from current unsustainable farming practices to sustainable farming systems. Better designed, more flexible, and more diverse options are required, given the contribution of current agricultural practices to global GHG emissions [97].

Moreover, there is a need for low threshold incentives that make it easier for farmers who have not yet adopted any sustainable agricultural practices to transition to a new practice(s) and eventually to a new farming system. Another constraint is the complexity of some of the regulatory incentives, such as watershed management programs and forest laws, which demotivate farmers to adopt or even consider adoption. Given the necessary scale for profitable farms and incumbent mechanization, the adoption of sustainable agricultural practices often has very high initial investment costs for which there are no good adequate financing options. This makes it very difficult for less well-resourced farmers to adopt. Although there are top-down incentives that are mandatory, such as cross-compliance and greening requirements of the CAP Pillar 1, the Natura 2000 sites (Habitats and Birds Directives), protection of water against pollution caused by nitrates (Nitrate Directive) and voluntary incentives, such as Agri-environment payment schemes or Payment for Ecosystem Services, which are offered to farmers, these incentives do not take into account a household's short-term economic needs [96].

\subsubsection{Low Level of Education and Awareness}

There is still limited scientific knowledge and limited practical on-farm experiences concerning sustainable agricultural practices, which contributes to a lack of awareness amongst farmers of practices, such as direct seeding and relay intercropping, and the use of natural pesticides, no-tillage, and application of biopesticides and agroforestry [20,98]. The education of policy makers, producers, and consumers is essential to discover, understand, and promote sustainable farming practices for future adoption. For example, intercropping practices in particular offer many advantages, but improved understanding of the ecological mechanisms associated with different crop components, planned temporal and spatial diversity, and the benefits derived from associated diversity, is needed to better identify and quantify all the possible benefits. Moreover, the application of the different sustainable agricultural practices presented in this article implies modifying the farming system, either at crop management scale or at the cropping or farming system scale. When a much larger part of the system has to be reorganized or redesigned, it requires in-depth knowledge about different crop choices and their complementarity in resource use that can enhance yields without compromising the yield of the main crop [61,99]. Thus, to enhance the rate of adoption, technical assistance, training to improve farmers' capacity to adapt technologies 
to their own situation, and training of extension agents to share the knowledge and practical aspects, are crucial.

\subsubsection{Lack of and Limited Field Demonstrations}

This study has provided a comprehensive analysis of multiple benefits and tradeoffs of the most popular sustainable production practices in European and North African contexts. Further research into this area should provide field-based evidence of the multiple benefits and trade-offs. This could be done by establishing demonstration sites under different pedo-climatic and socio-economic conditions where farm managers and farmers can see the benefits of upscaling the adoption of sustainable agricultural methods for tangible effects at farm, national and regional and continental scales. There is a need to expand the focus of agricultural research from field and plot research to landscape research and assess the costs of the production transition by internalizing environmental costs [100]. On-field demonstration and farmer-to-farmer exchange programs are useful for motivating farmers to shift their practices in this regard. This kind of citizen (research) involvement is a very practical way to contribute to the implementation of the revised European Union CAP and its core proposed measures (Eco-schemes; Enhanced conditionality; and Agrienvironment-climate measures) [101]. The on-farm agronomic and environmental research can be complemented by research of new marketing modalities and opportunities (e.g., niche product development, 'buying local' initiatives, product certification schemes), the roles of agri-food sector companies in sustainable supply chain [102], and the use of digital technologies (e.g., real-time price updates, on-line fresh products ordering, e-payment options, tracing and tracking of products). All these research efforts can contribute to overcome the main barriers to increased adoption of sustainable agricultural practices and to reap the benefits of these practices.

\section{Conclusions}

Farmers in Europe and North Africa have been slow to adopt CA, organic agriculture, agroforestry, and other forms of sustainable agricultural practices, despite the multiple benefits they generate. The soil, water, and nutrient conservation practices reviewed in this paper are imperative to reduce runoff, soil erosion, improve soil quality, water quality, and moisture conservation, and enhance overall crop productivity. Together, these practices in Europe and North Africa can reduce operational costs, increase soil, water, and nutrient conservation, while also increasing crop yields. Moreover, adopting these practices can increase sustainable food production to meet food security.

There are evident scale impacts of adopting sustainable agricultural practices ranging from field to catchment levels, but the best empirical evidence has been generated at the field level. Despite the demonstrated benefits of these practices in different contexts, there are tradeoffs to consider as well. For example, CA practices (such as no-tillage and the application of residues/mulch) in regions of negative winter water deficits (i.e., water surplus), such as northern and western Europe, can result in problems of water-logged soil, harboring of disease and pests, and cold soil hindering germination. On the other hand, the high positive summer water deficits in southwestern Europe and North Africa do merit the use of CA practices for retention of soil water. Therefore, time-space bound water deficit values at a site can guide decisions on the application of a certain practice or practices. Similarly, the effects of these practices on the indicators will vary, as they are influenced by factors such as crop species, aridity index, irrigation use/rainfed, and soil type. Yield performance and stability, operating costs, climate change, and environmental policies and incentives, education and awareness programs, and field demonstrations, will likely be the major driving forces defining the direction and rate of adoption of sustainable agricultural practices. The adoption of sustainable farming practices requires significant efforts from farmers and support of government at national and local levels. To make site-specific recommendations, a careful assessment of overall benefits must be made. 
This can be achieved via crop-system modelling, which is one method of addressing the exigent needs of improving our understanding of the complex spatial, temporal, and crop component interactions. As Malézieux et al. 2009 [22] discuss, there is an evident need to design agricultural systems, especially complex ones like intercropping, using models. These models must be applicable to multispecies systems in order to account for the interactions between components, long-term cumulative effects, and multifaceted objectives of crops. The complexity of the interactions necessitates the development of new knowledge; this cannot simply be achieved via studies on plant components independently [103], nor can it be achieved via traditional factorial experimental approaches [22]. Continued investment in crop-system modelling can help to give farmers tools and knowledge to tailor their management to their given context, at a variety of scales. Adoption of sustainable agricultural practices can further be stimulated when farmers have the opportunity to experiment on their own land and discover the advantages and disadvantages of different practices. Research and the expertise of more "advanced" farmers can help guide the decision process as well, utilizing peer-to-peer networks to spread the much-needed transition.

Author Contributions: T.C. and B.B.G. researched, selected and reviewed the literature. T.C. designed and drafted the article. B.B.G. did the final editing and mobilized the funding for the manuscript. All authors have read and agreed to the published version of the manuscript.

Funding: This research was funded by the WaterFARMING (grant agreement no: 689271) project and SustainFARM project (Grant Agreement No: 652615) which are acknowledged for support for the preparation of the manuscript.

Institutional Review Board Statement: Not applicable.

Informed Consent Statement: Not applicable.

Data Availability Statement: Data are contained within the article.

Acknowledgments: We thank Robin Sears for assistance with the literature search and review and Ronnie Vernooy of the Alliance of Bioversity International and CIAT for feedback on the draft article, and Reed John Cowden for the review of the revised article. We thank the anonymous reviewers for the useful comments and suggestions.

Conflicts of Interest: The authors declare no conflict of interest.

\section{References}

1. Kremen, C.; Iles, A.; Bacon, C. Diversified farming systems: An agroecological, systems-based alternative to modern industrial agriculture. Ecol. Soc. 2012, 17. [CrossRef]

2. Frison, E.A. From Uniformity to Diversity: A Paradigm Shift from Industrial Agriculture to Diversified Agroecological Systems. 2016. Available online: https:/ / www.researchgate.net/publication/303737887 (accessed on 7 January 2021).

3. Parris, K. Impact of agriculture on water pollution in OECD countries: Recent trends and future prospects. Int. J. Water Res. Dev. 2011, 27, 33-52. [CrossRef]

4. WWAP. The United Nations World Water Development Report 2015: Water for a Sustainable World; United Nations World Water Assessment Programme (WWAP), United Nations Educational, Scientific and Cultural Organization: Paris, France, 2015.

5. Kopittke, P.M.; Menzies, N.W.; Wang, P.; McKenna, B.A.; Lombi, E. Soil and the intensification of agriculture for global food security. Environ. Int. 2019, 132, 105078. [CrossRef]

6. Tamburini, G.; Bommarco, R.; Wanger, T.C.; Kremen, C.; van der Heijden, M.G.A.; Liebman, M.; Hallin, S. Agricultural diversification promotes multiple ecosystem services without compromising yield. Sci. Adv. 2020, 6, eaba1715. [CrossRef]

7. Timsina, J. Can Organic Sources of Nutrients Increase Crop Yields to Meet Global Food Demand? Agronomy 2018, 8, 214. [CrossRef]

8. Beillouin, D.; Ben-Ari, T.; Makowski, D. Evidence map of crop diversification strategies at the global scale. Environ. Res. Lett. 2019, 14, 123001. [CrossRef]

9. Ceglar, A.; Zampieri, M.; Toreti, A.; Dentener, F. Observed Northward Migration of Agro-Climate Zones in Europe Will Further Accelerate under Climate Change. Earth's Future 2019, 7, 1088-1101. [CrossRef]

10. Iglesias, A.; Garrote, L.; Quiroga, S.; Moneo, M. A regional comparison of the effects of climate change on agricultural crops in Europe. Clim. Chang. 2012, 112, 29-46. [CrossRef]

11. Stagge, J.H.; Kingston, D.G.; Tallaksen, L.M.; Hannah, D.M. Observed drought indices show increasing divergence across Europe. Sci. Rep. 2017, 7, 14045. [CrossRef] [PubMed] 
12. Trnka, M.; Hlavinka, P.; Semenov, M.A. Adaptation options for wheat in Europe will be limited by increased adverse weather events under climate change. J. R. Soc. Interface 2015, 12, 20150721. [CrossRef]

13. Porter, J.R.; Xie, L.; Challinor, A.J.; Cochrane, K.; Howden, S.M.; Iqbal, M.M.; Lobell, D.B.; Travasso, M.I. Food security and food production systems. In Climate Change 2014: Impacts, Adaptation, and Vulnerability. Working Group II contribution to the Fifth Assessment Report of the Intergovernmental Panel on Climate Change; Field, C.B., Barros, V.R., Dokken, D.J., Mach, K.J., Mastrandrea, M.D., Bilir, T.E., Chatterjee, M., Ebi, K.L., Estrada, Y.O., Genova, R.C., et al., Eds.; Cambridge University Press: Cambridge, UK, 2014; pp. 485-533. Available online: https://www.ipcc.ch/site/assets/uploads/2018/02/WGIIAR5-Chap7_FINAL.pdf (accessed on 7 January 2021).

14. Ray, D.K.; Gerber, J.S.; MacDonald, G.K.; West, P.C. Climate variation explains a third of global crop yield variability. Nat. Commun. 2015, 6, 5989. [CrossRef]

15. Bahri, H.; Annabi, M.; Cheikh M'Hamed, H.; Frija, A. Assessing the long-term impact of conservation agriculture on wheat-based systems in Tunisia using APSIM simulations under a climate change context. Sci. Total Environ. 2019, 692, 1223-1233. [CrossRef]

16. Lagacherie, P.; Álvaro-Fuentes, J.; Annabi, M.; Bernoux, M.; Bouarfa, S.; Douaoui, A.; Grünberger, O.; Hammani, A.; Montanarella L.; Mrabet, R.; et al. Managing Mediterranean soil resources under global change: Expected trends and mitigation strategies. Reg. Environ. Chang. 2018, 18, 663-675. [CrossRef]

17. Lewandowski, J.; Meinikmann, K.; Nützmann, G.; Rosenberry, D.O. Groundwater-The disregarded component in lake water and nutrient budgets. Part 2: Effects of groundwater on nutrients. Hydrol. Process. 2015, 29, 2922-2955. [CrossRef]

18. Lee, H.; Lautenbach, S.; Paula, A.; García-Nieto, A.; Bondeau, A.; Cramer, W.; Geijzendorffer, I.R. The impact of conservation farming practices on Mediterranean agro-ecosystem services provisioning-A meta analysis. Reg. Environ. Chang. 2019. [CrossRef]

19. Czyżewski, B.; Matuszczak, A.; Muntean, A. Approaching environmental sustainability of agriculture: Environmental burden, eco-efficiency or eco-effectiveness. Agric. Econ. 2019, 65, 299-306. [CrossRef]

20. Wezel, A.; Casagrande, M.; Celette, F.; Vian, J.F.; Ferrer, A.; Peigné, J. Agroecological practices for sustainable agriculture. A review. Agron. Sustain. Dev. 2014, 34, 1-20. [CrossRef]

21. Garbach, K.; Milder, J.C.; DeClerck, F.A.; Montenegro de Wit, M.; Driscoll, L.; Gemmill-Herren, B. Examining multi-functionality for crop yield and ecosystem services in five systems of agroecological intensification. Int. J. Agric. Sustain. 2017, 15, 11-28. [CrossRef]

22. Malézieux, E.; Crozat, Y.; Dupraz, C.; Laurans, M.; Makowski, D.; Ozier-Lafontaine, H.; Rapidel, B.; De Tourdonnet, S.; ValantinMorison, M. Mixing plant species in cropping systems: Concepts, tools and models: A review. Sustain. Agric. 2009, 329-353. [CrossRef]

23. Palm, C.; Blanco-Canqui, H.; DeClerck, F.; Gatere, L.; Grace, P. Conservation agriculture and ecosystem services: An overview. Agric. Ecosyst. Environ. 2014, 187, 87-105. [CrossRef]

24. Van den Putte, A.; Govers, G.; Diels, J.; Gillijns, K.; Demuzere, M. Assessing the effect of soil tillage on crop growth: A meta-regression analysis on European crop yields under conservation agriculture. Eur. J. Agron. 2010, 33, 231-241. [CrossRef]

25. Scopel, E.; Triomphe, B.; Affholder, F.; Da Silva, F.A.M.; Corbeels, M.; Xavier, J.H.V.; Lahmar, R.; Recous, S.; Bernoux, M.; Blanchart, E.; et al. Conservation agriculture cropping systems in temperate and tropical conditions, performances and impacts. A review. Agron. Sustain. Dev. 2013, 33, 113-130. [CrossRef]

26. Kassam, A.; Friedrich, T.; Derpsch, R. Global spread of Conservation Agriculture. Int. J. Environ. Stud. 2019, 76, 29-51. [CrossRef]

27. Soane, B.D.; Ball, B.C.; Arvidsson, J.; Basch, G.; Moreno, F.; Roger-Estrade, J. No-till in northern, western and south-western Europe: A review of problems and opportunities for crop production and the environment. Soil Tillage Res. 2012, 118 , 66-87. [CrossRef]

28. Pittelkow, C.M.; Linquist, B.A.; Lundy, M.E.; Liang, X.; van Groenigen, K.J.; Lee, J.; van Gestel, N.; Six, J.; Venterea, R.T.; van Kessel, C. When does no-till yield more? A global meta-analysis. Field Crop. Res. 2015, 183, 156-168. [CrossRef]

29. Cooper, J.; Baranski, M.; Stewart, G.; Nobel-de Lange, M.; Bàrberi, P.; Fließbach, A.; Peigné, J.; Berner, A.; Brock, C.; Casagrande, M.; et al. Shallow non-inversion tillage in organic farming maintains crop yields and increases soil C stocks: A meta-analysis. Agron. Sustain. Dev. 2016, 36, 22. [CrossRef]

30. Verret, V.; Gardarin, A.; Pelzer, E.; Médiène, S.; Makowski, D.; Valantin-Morison, M. Can legume companion plants control weeds without decreasing crop yield? A meta-analysis. Field Crops Res. 2017, 204, 158-168. [CrossRef]

31. Fan, X.; Vrieling, A.; Muller, B.; Nelson, A. Winter cover crops in Dutch maize fields: Variability in quality and its drivers assessed from multi-temporal Sentinel-2 imagery. Int. J. Appl. Earth Obs. Geoinf. 2020, 91, 102139. [CrossRef]

32. Gerhards, R.; Schappert, A. Advancing cover cropping in temperate integrated weed management. Pest Manag. Sci. 2020, 76, 42-46. [CrossRef] [PubMed]

33. Tarricone, L.; Debiase, G.; Masi, G.; Gentilesco, G.; Montemurro, F. Cover Crops Affect Performance of Organic Scarlotta Seedless Table Grapes under Plastic Film Covering in Southern Italy. Agronomy 2020, 10, 550. [CrossRef]

34. Marinari, S.; Mancinelli, R.; Brunetti, P.; Campiglia, E. Soil quality, microbial functions and tomato yield under cover crop mulching in the Mediterranean environment. Soil Tillage Res. 2015, 145, 20-28. [CrossRef]

35. Zayton, A.; Guirguis, A.; Allam, K. Effect of mulching type and duration on the productivity and water use efficiency of potato. $J$. Soil Sci. Agric. Eng. 2015, 6, 719-733. [CrossRef] 
36. Kruidhof, H.M.; Bastiaans, L.; Kropff, M.J. Cover crop residue management for optimizing weed control. Plant Soil 2009, 318, 169-184. [CrossRef]

37. Pannell, D.J.; Llewellyn, R.S.; Corbeels, M. The farm-level economics of conservation agriculture for resource-poor farmers. Agric. Ecosyst. Environ. 2014, 187, 52-64. [CrossRef]

38. Rillig, M.C.; Mummey, D.L. Mycorrhizas and soil structure. New Phytol. 2006, 171, 41-53. [CrossRef] [PubMed]

39. Harb, O.; El-Hay, A.; Hager, M.; El-Enin, A. Studies on conservation agriculture in Egypt. Ann. Agric. Sci. 2015, 60, 105-112. [CrossRef]

40. Souissi, A.; Bahri, H.; Cheikh M'hamed, H.; Chakroun, M.; Benyoussef, S.; Frija, A.; Annabi, M. Effect of Tillage, Previous Crop, and N Fertilization on Agronomic and Economic Performances of Durum Wheat (Triticum durum Desf.) under Rainfed Semi-Arid Environment. Agronomy 2020, 10, 1161. [CrossRef]

41. Gruber, S.; Pekrun, C.; Möhring, J.; Claupein, W. Long-term yield and weed response to conservation and stubble tillage in SW Germany. Soil Tillage Res. 2012, 121, 49-56. [CrossRef]

42. Zikeli, S.; Gruber, S. Reduced Tillage and No-Till in Organic Farming Systems, Germany-Status Quo, Potentials and Challenges. Agriculture 2017, 7, 35. [CrossRef]

43. Koch, H.-J.; Dieckmann, J.; Büchse, A.; Märländer, B. Yield decrease in sugar beet caused by reduced tillage and direct drilling. Eur. J. Agron. 2009, 30, 101-109. [CrossRef]

44. Weber, J.F.; Kunz, C.; Peteinatos, G.G.; Zikeli, S.; Gerhards, R. Weed Control Using Conventional Tillage, Reduced Tillage, No-Tillage, and Cover Crops in Organic Soybean. Agriculture 2017, 7, 43. [CrossRef]

45. Chen, H.; Marhan, S.; Billen, N.; Stahr, K. Soil organic-carbon and total nitrogen stocks as affected by different land uses in Baden-Württemberg (southwest Germany). J. Plant Nutr. Soil Sci. 2009, 172, 32-42. [CrossRef]

46. Jemai, I.; Ben Aissa, N.; Ben Guirat, S.; Ben-Hammouda, M.; Gallali, T. Impact of three and seven years of no-tillage on the soil water storage, in the plant root zone, under a dry subhumid Tunisian climate. Soil Tillage Res. 2013, 126, 26-33. [CrossRef]

47. Bahri, H.; Annabi, M.; Saoueb, A.; M’Hamed, H.C.; Souissi, A.; Chibani, R.; Bahri, B.A. Can Conservation Agriculture Sequester Soil Carbon in Northern Tunisia in the Long Run? Springer International Publishing: Cham, Switzerland, 2018; Volume 87, pp. 85-87. [CrossRef]

48. Ben Moussa-Machraoui, S.; Errouissi, F.; Ben-Hammouda, M.; Nouira, S. Comparative effects of conventional and no-tillage management on some soil properties under Mediterranean semi-arid conditions in northwestern Tunisia. Soil Tillage Res. 2010, 106, 247-253. [CrossRef]

49. Salem, H.M.; Valero, C.; Muñoz, M.Á.; Gil-Rodríguez, M. Effect of integrated reservoir tillage for in-situ rainwater harvesting and other tillage practices on soil physical properties. Soil Tillage Res. 2015, 151, 50-60. [CrossRef]

50. Lampurlanés, J.; Plaza-Bonilla, D.; Álvaro-Fuentes, J.; Cantero-Martínez, C. Long-term analysis of soil water conservation and crop yield under different tillage systems in Mediterranean rainfed conditions. Field Crop. Res. 2016, 189, 59-67. [CrossRef]

51. Abdollahi, L.; Munkholm, L.J. Tillage System and Cover Crop Effects on Soil Quality: I Chemical, Mechanical, and Biological Properties. Soil Sci. Soc. Am. J. 2014, 78, 262-270. [CrossRef]

52. Piccoli, I.; Chiarini, F.; Carletti, P.; Furlan, L.; Lazzaro, B.; Nardi, S.; Berti, A.; Sartori, L.; Dalconi, M.C.; Morari, F. Disentangling the effects of conservation agriculture practices on the vertical distribution of soil organic carbon. Evidence of poor carbon sequestration in North- Eastern Italy. Agric. Ecosyst. Environ. 2016, 230, 68-78. [CrossRef]

53. Ghaley, B.B.; Rusu, T.; Sandén, T.; Spiegel, H.; Menta, C.; Visioli, G.; O’Sullivan, L.; Gattin, I.T.; Delgado, A.; Liebig, M.A.; et al. Assessment of benefits of conservation agriculture on soil functions in arable production systems in Europe. Sustainability 2018, 10, 794. [CrossRef]

54. Steinmann, H.-H.; Dobers, E.S. Spatio-temporal analysis of crop rotations and crop sequence patterns in Northern Germany: Potential implications on plant health and crop protection. J. Plant Dis. Prot. 2013, 120, 85-94. [CrossRef]

55. Rasmussen, I.A.; Askegaard, M.; Olesen, J.E.; Kristensen, K. Effects on weeds of management in newly converted organic crop rotations in Denmark. Agric. Ecosyst. Environ. 2006, 113, 184-195. [CrossRef]

56. Mechri, M.; Patil, S.; Saidi, W.; Hajri, R.; Jarrahi, T.; Gharbi, A.; Jedidi, N. Soil organic carbon and nitrogen status under fallow and cereal-legume species in a Tunesian semi-arid conditions. Eur. J. Earth Environ. 2016, 3, 1-13.

57. Khemir, E.; Chekali, S.; Moretti, A.; Gharbi, M.S.; Allagui, M.B.; Gargouri, S. Impacts of previous crops on inoculum of Fusarium culmorum in soil, and development of foot and root rot of durum wheat in Tunisia. Phytopathol. Mediterr. 2020, 59, 187-201. [CrossRef]

58. Ben Zekri, Y.; Barkaoui, K.; Marrou, H.; Mekki, I.; Belhouchette, H.; Wery, J. On farm analysis of the effect of the preceding crop on $\mathrm{N}$ uptake and grain yield of durum wheat (Triticum durum Desf.) in Mediterranean conditions. Arch. Agron. Soil Sci. 2019, 65, 596-611. [CrossRef]

59. Abdel-Monaim, M.F.; Abo-Elyousr, K.A.M. Effect of preceding and intercropping crops on suppression of lentil damping-off and root rot disease in New Valley-Egypt. Crop Prot. 2012, 32, 41-46. [CrossRef]

60. Deike, S.; Pallutt, B.; Melander, B.; Strassemeyer, J.; Christen, O. Long-term productivity and environmental effects of arable farming as affected by crop rotation, soil tillage intensity and strategy of pesticide use: A case-study of two long-term field experiments in Germany and Denmark. Eur. J. Agron. 2008, 29, 191-199. [CrossRef]

61. Nemecek, T.; von Richthofen, J.-S.; Dubois, G.; Casta, P.; Charles, R.; Pahl, H. Environmental impacts of introducing grain legumes into European crop rotations. Eur. J. Agron. 2008, 28, 380-393. [CrossRef] 
62. Ouma, G.; Jeruto, P. Sustainable horticultural crop production through intercropping: The case of fruits and vegetable crops: A review. Agric. Biol. J. N. Am. 2010, 1, 1098-1105. [CrossRef]

63. Götze, P.; Rücknagel, J.; Jacobs, A.; Märländer, B.; Koch, H.-J.; Holzweißig, B.; Steinz, M.; Christen, O. Sugar beet rotation effects on soil organic matter and calculated humus balance in Central Germany. Eur. J. Agron. 2016, 76, 198-207. [CrossRef]

64. Bedoussac, L.; Journet, E.-P.; Hauggaard-Nielsen, H.; Naudin, C.; Corre-Hellou, G.; Jensen, E.S.; Prieur, L.; Justes, E. Ecological principles underlying the increase of productivity achieved by cereal-grain legume intercrops in organic farming. A review. Agron. Sustain. Dev. 2015, 35, 911-935. [CrossRef]

65. Raseduzzaman, M.; Jensen, E.S. Does intercropping enhance yield stability in arable crop production? A meta-analysis. Eur. J. Agron. 2017, 91, 25-33. [CrossRef]

66. Hauggaard-Nielsen, H.; Jørnsgaard, B.; Kinane, J.; Jensen, E.S. Grain Legume-Cereal Intercropping: The Practical Application of Diversity, Competition and Facilitation in Arable and Organic Cropping Systems. Renew. Agric. Food Syst. 2008, $23,3-12$. Available online: https:/ / www.jstor.org/stable/44473559 (accessed on 7 January 2021). [CrossRef]

67. Jensen, E.S.; Carlsson, G.; Hauggaard-Nielsen, H. Intercropping of grain legumes and cereals improves the use of soil N resources and reduces the requirement for synthetic fertilizer N: A global-scale analysis. Agron. Sustain. Dev. 2020, 40, 5. [CrossRef]

68. Rodriguez, C.; Carlsson, G.; Englund, J.-E.; Flöhr, A.; Pelzer, E.; Jeuffroy, M.-H.; Makowski, D.; Jensen, E.S. Grain legume-cereal intercropping enhances the use of soil-derived and biologically fixed nitrogen in temperate agroecosystems. A meta-analysis. Eur. J. Agron. 2020, 118, 126077. [CrossRef]

69. Xu, Z.; Li, C.; Zhang, C.; Yu, Y.; van der Werf, W.; Zhang, F. Intercropping maize and soybean increases efficiency of land and fertilizer nitrogen use: A meta-analysis. Field Crop. Res. 2020, 246, 107661. [CrossRef]

70. Scalise, A.; Tortorella, D.; Pristeri, A.; Petrovičová, B.; Gelsomino, A.; Lindström, K.; Monti, M. Legume-barley intercropping stimulates soil $\mathrm{N}$ supply and crop yield in the succeeding durum wheat in a rotation under rainfed conditions. Soil Biol. Biochem. 2015, 89, 150-161. [CrossRef]

71. Chapagain, T.; Riseman, A. Barley-pea intercropping: Effects on land productivity, carbon and nitrogen transformations. Field Crop. Res. 2014, 166, 18-25. [CrossRef]

72. Yin, W.; Chai, Q.; Zhao, C.; Yu, A.; Fan, Z.; Hu, F.; Fan, H.; Guo, Y.; Coulter, J.A. Water utilization in intercropping: A review. Agric. Water Manag. 2020, 241, 106335. [CrossRef]

73. Kubota, A.; Safina, S.A.; Shebl, S.M.; Mohamed, A.E.-D.H.; Ishikawa, N.; Shimizu, K.; Abdel-Gawad, K.; Maruyama, S. Evaluation of intercropping system of maize and leguminous crops in the Nile Delta of Egypt. Trop. Agric. Dev. 2015, 59, 14-19. [CrossRef]

74. Thorsted, M.D.; Olesen, J.E.; Weiner, J. Width of clover strips and wheat rows influence grain yield in winter wheat/white clover intercropping. Field Crop. Res. 2006, 95, 280-290. [CrossRef]

75. Peigné, J.; Casagrande, M.; Payet, V.; David, C.; Sans, F.X.; Blanco-Moreno, J.M.; Cooper, J.; Gascoyne, K.; Antichi, D.; Bàrberi, P.; et al. How organic farmers practice conservation agriculture in Europe. Renew. Agric. Food Syst. 2016, 31, 72-85. [CrossRef]

76. Oelofse, M.; Jensen, L.S.; Magid, J. The implications of phasing out conventional nutrient supply in organic agriculture: Denmark as a case. Org. Agric. 2013, 3, 41-55. [CrossRef]

77. Pandey, A.; Li, F.; Askegaard, M.; Olesen, J.E. Biological nitrogen fixation in three long-term organic and conventional arable crop rotation experiments in Denmark. Eur. J. Agron. 2017, 90, 87-95. [CrossRef]

78. Pandey, A.; Li, F.; Askegaard, M.; Rasmussen, I.A.; Olesen, J.E. Nitrogen balances in organic and conventional arable crop rotations and their relations to nitrogen yield and nitrate leaching losses. Agric. Ecosyst. Environ. 2018, 265, 350-362. [CrossRef]

79. Pulleman, M.; Jongmans, A.; Marinissen, J.; Bouma, J. Effects of organic versus conventional arable farming on soil structure and organic matter dynamics in a marine loam in the Netherlands. Soil Use Manag. 2003, 19, 157-165. [CrossRef]

80. Shahin, R.R.; Khater, H.A. Quality and quantity of soil organic matter as affected by the period of organic farming in Sekem farm, Egypt. Eurasian J. Soil Sci. 2020, 9, 275-281. [CrossRef]

81. Knudsen, M.T.; Kristensen, I.S.; Berntsen, J.; Petersen, B.M.; Kristensen, E.S. Estimated N leaching losses for organic and conventional farming in Denmark. J. Agric. Sci. 2006, 144, 135-149. [CrossRef]

82. Biernat, L.; Taube, F.; Vogeler, I.; Reinsch, T.; Kluß, C.; Loges, R. Is organic agriculture in line with the EU-Nitrate directive? On-farm nitrate leaching from organic and conventional arable crop rotations. Agric. Ecosyst. Environ. 2020, $298,106964$. [CrossRef]

83. De Olde, E.M.; Oudshoorn, F.W.; Bokkers, E.A.M.; Stubsgaard, A.; Sørensen, C.A.G.; De Boer, I.J.M. Assessing the Sustainability Performance of Organic Farms in Denmark. Sustainability 2016, 8, 957. [CrossRef]

84. Conti, S.; Villari, G.; Faugno, S.; Melchionna, G.; Somma, S.; Caruso, G. Effects of organic vs. conventional farming system on yield and quality of strawberry grown as an annual or biennial crop in southern Italy. Sci. Hortic. 2014, 180, 63-71. [CrossRef]

85. Palma, J.; Crous-Duran, J.; Graves, A.; Burgess, P.J. Database of Agroforestry System Descriptions; Agforward Project: EU. 2015. Available online: https:/ / www.repository.utl.pt/handle/10400.5/14796 (accessed on 7 January 2021).

86. Camilli, F.; Pisanelli, A.; Seddaiu, G.; Franca, A.; Bondesan, V.; Rosati, A.; Moreno, G.; Pantera, A.; Hermansen, J.; Burgess, P. Benefits and constraints associated to agroforestry systems: The case studies implemented in Italy within the Agforward project. In Proceedings of the 3rd European Agroforestry Conference Montpellier (2016 EURAF), Montpellier, France, 23-25 May 2016; Available online: https://www.repository.utl.pt/bitstream/10400.5/17410/1/EURAFIIIConf_Camilli_F_et_all_page_20_23.pdf (accessed on 7 January 2021). 
87. Brunori, E.; Maesano, M.; Moresi, F.V.; Matteucci, G.; Biasi, R.; Scarascia Mugnozza, G. The hidden land conservation benefits of olive-based (Olea europaea L.) landscapes: An agroforestry investigation in the southern Mediterranean (Calabria region, Italy). Land Degrad. Dev. 2020, 31, 801-815. [CrossRef]

88. Beuschel, R.; Piepho, H.-P.; Joergensen, R.G.; Wachendorf, C. Similar spatial patterns of soil quality indicators in three poplar-based silvo-arable alley cropping systems in Germany. Biol. Fertil. Soils 2019, 55, 1-14. [CrossRef]

89. Moreno, G.; Arenas, G.; López-Díaz, M.L.; Bertomeu, Y.C.; Juarez, E. Cereal Production beneath Walnut for Quality Timber Production in Spain; Agforward Project; EU: Brussels, Belgium, 2015.

90. Eichhorn, M.P.; Paris, P.; Herzog, F.; Incoll, L.D.; Liagre, F.; Mantzanas, K.; Mayus, M.; Moreno, G.; Papanastasis, V.P.; Pilbeam, D.J.; et al. Silvoarable Systems in Europe-Past, Present and Future Prospects. Agrofor. Syst. 2006, 67, 29-50. [CrossRef]

91. Markwitz, C.; Knohl, A.; Siebicke, L. Evapotranspiration over agroforestry sites in Germany. Biogeosciences 2020, 17, 5183-5208. [CrossRef]

92. Lin, H.-C.; Hülsbergen, K.-J. A new method for analyzing agricultural land-use efficiency, and its application in organic and conventional farming systems in southern Germany. Eur. J. Agron. 2017, 83, 15-27. [CrossRef]

93. Casagrande, M.; Peigné, J.; Payet, V.; Mäder, P.; Sans, F.X.; Blanco-Moreno, J.M.; Antichi, D.; Bàrberi, P.; Beeckman, A.; Bigongiali, F.; et al. Organic farmers' motivations and challenges for adopting conservation agriculture in Europe. Org. Agric. 2016, 6, 281-295. [CrossRef]

94. Long, T.B.; Blok, V.; Coninx, I. Barriers to the adoption and diffusion of technological innovations for climate-smart agriculture in Europe: Evidence from the Netherlands, France, Switzerland and Italy. J. Clean. Prod. 2016, 112, 9-21. [CrossRef]

95. Hernández-Morcillo, M.; Burgess, P.J.; Mirck, J.; Pantera, A.; Plieninger, T. Scanning agroforestry-based solutions for climate change mitigation and adaptation in Europe. Environ. Sci. Policy 2018, 80, 44-52. [CrossRef]

96. Piñeiro, V.; Arias, J.; Dürr, J.; Elverdin, P.; Ibáñez, A.M.; Kinengyere, A.; Opazo, C.M.; Owoo, N.; Page, J.R.; Prager, S.D.; et al. A scoping review on incentives for adoption of sustainable agricultural practices and their outcomes. Nat. Sustain. 2020, 3, 809-820. [CrossRef]

97. Kassam, A.H.; Friedrich, T.; Derpsch, R. Conservation agriculture in the 21st century: A paradigm of sustainable agriculture. In Proceedings of the European Congress on Conservation Agriculture 2010, Madrid, Spain, 4-7 October 2010; Volume 10, pp. 4-6.

98. Gómez, J.A.; Guzmán, G.; Giráldez, J.V.; Fereres, E. The influence of cover crops and tillage on water and sediment yield, and on nutrient, and organic matter losses in an olive orchard on a sandy loam soil. Soil Tillage Res. 2009, 106, 137-144. [CrossRef]

99. Palma, J.; Graves, A.; Burgess, P.J.; Van Der Werf, W.; Herzog, F. Integrating environmental and economic performance to assess modern silvoarable agroforestry in Europe. Ecol. Econ. 2007, 63, 759-767. [CrossRef]

100. Vlek, P.L.; Khamzina, A.; Azadi, H.; Bhaduri, A.; Bharati, L.; Braimoh, A.; Martius, C.; Sunderland, T.; Taheri, F. Trade-offs in multi-purpose land use under land degradation. Sustainability 2017, 9, 2196. [CrossRef]

101. European Commission. Working with Parliament and Council to Make the CAP Reform Fit for the European Green Deal; European Commission: 2020. Available online: https://ec.europa.eu/info/sites/info/files/food-farming-fisheries/key_policies/ documents / factsheet-cap-reform-to-fit-european-green-deal_en.pdf (accessed on 7 January 2021).

102. Fortunati, S.; Morea, D.; Mosconi, E.M. Circular economy and corporate social responsibility in the agricultural system: Cases study of the Italian agri-food industry. Agric. Econ. 2020, 66, 489-498. [CrossRef]

103. House, J.I.; Archer, S.; Breshears, D.D.; Scholes, R.J. NCEAS Tree-Grass Interactions Participants. Conundrums in mixed woody-herbaceous plant systems. J. Biogeogr. 2003, 30, 1763-1777. [CrossRef] 